Human and Animal Health

Vol.59: e16160076, January-December 2016 http://dx. doi.org/10.1590/1678-4324-2016160076 ISSN 1678-4324 Online Edition

BRAZILIAN ARCHIVES OF BIOLOGY AND TECHNOLOGY

AN INTERNATIONAL JOURNAL

\title{
Diel Variations and Ecological Aspects in Fish Assemblages of a Sandy Beach in the Semi-Arid Region of Northeast Brazil.
}

\author{
Natália Carla Fernandes Medeiros Dantas ${ }^{1}$, Carlos Antônio Beserra Silva Júnior ${ }^{2}$, Daniel \\ Lino Lippi ${ }^{3}$, Caroline Vieira Feitosa ${ }^{1 *}$. \\ ${ }^{1}$ Universidade Federal do Ceará, Fortaleza, Ceará, Brasil; ${ }^{2}$ Universidade Federal Rural de Pernambuco, Recife, \\ Brasil ; ${ }^{3}$ Universidade Fedral de Pernambuco, Departamento de Oceanografia, Recife, Brasil.
}

\begin{abstract}
For the demersal fish that inhabit sandy beaches, the variation between day and night periods represents a determinant factor in their behavior, especially for species that live in shallow waters. This research aims at determining whether there are differences in the fish assemblage structure of the sandy beach of São Cristóvão, RN, Brazil, between diurnal and nocturnal periods. Samplings were carried out in 2011, during spring high tide period, with an otter trawl net. Dissimilarity between diurnal and nocturnal fish assemblages was confirmed by PERMANOVA results. No statistical differences were observed for richness and diversity of fish assemblage between day and night periods. The first and third order carnivores were the significantly more representative trophic categories during night and day periods, respectively. Only four species presented significant differences regarding total length of fish between the periods. The demersal fish assemblage of São Cristóvão beach presented variations in the density of individuals between day and night periods. Dissimilarities were also recorded in trophic categories and in total lengths of individuals; however this occurred as a result of the high density of some species. The low depth of the beach may prevent the establishment of larger size adult fish, thus becoming a favourable environment for juveniles and small-sized fish species.
\end{abstract}

Key words: demersal ichthyofauna, density, diversity, total length, day, night.

\footnotetext{
*Authors for correspondence: carol_feitosa@hotmail.com
} 


\section{INTRODUCTION}

For the demersal fishes that inhabit sandy beaches, lighting variation between day and night periods and tidal cycles represent a determinant factor in their behavior, especially for individuals that live in shallow waters (Rountre \& Able, 1993; Paiva et al., 2009). Moreover, the incident light exerts influence on the abundance of many species, changing in the composition and richness of fish assemblages (Clark et al., 1996).

These changes in fish community may be associated with the use of the sandy beach at different times of the day. This ecosystem can be used for diverse purposes, such as (1) daily movements among adjacent habitats, (2) changes in patterns of local activities (e.g. foraging and breeding activities, predator avoidance behavior) and (3) response to variations in the physical conditions (Rountree \& Able, 1993; Morrison et al., 2002; Ribeiro et al., 2006; Hagan \& Able, 2008). The behavior of the ichthyofauna along the diel light cycle differs among species, generating differences in catchability (Parsley et al., 1989). Thus, some species have a higher catch rate during the day while others have a higher catch rate at night (Nash \& Santos, 1998). In this context, the hypothesis that the fish assemblage is differentially structured between day and night period was tested.

In Brazil, some studies have been performed focusing on fish assemblages and nictemeral variations (Pessanha et al., 2003; Pessanha \& Araújo, 2003; Barreiros et al. 2005; Gaelzer \& Zalmon, 2008; Oliveira-Neto et al., 2008; FélixHackradt et al. 2010; Vasconcelos et al. 2010; Ribeiro et al. 2014). It is important to note that all publications refer to the South and Southeast regions. In addition, the variations between day and night are associated with seasons. Therefore, this research aims at filling the knowledge gap regarding nictemeral variations in fish assemblages of Northeastern Brazil.

In the north coast of Rio Grande do Norte, some activities as the salt industry, shrimp farming and trawling (Ibama, 2007; Idema, 2008), cause severe impacts that can modify the structure and dynamics of demersal fish assemblages in the region. The environmental effects of these activities are still unknown because studies in the area are scarce. This research will provide the basic information regarding structure patterns of the fish community and their nocturnal use of the area, which are important elements to understand the dynamics in fish populations of tropical sandy beaches. Thus, this research aims at determining whether there are differences in the fish assemblage structure of the sandy beach of São Cristóvão, RN, Brazil, between diurnal and nocturnal periods.

\section{MATERIALS AND METHODS}

São Cristóvão Beach $\left(4^{\circ} 55^{\prime} 29.83^{\prime \prime} \quad \mathrm{S}\right.$ and $36^{\circ} 57^{\prime} 2.91$ ' 'W), on the Northern coast of the State of Rio Grande do Norte (Figure 1), is characterized by the presence of a wide bay and the predominant substrate is sandy/muddy. This beach is located between two estuarine complexes: the Apodi-Mossoró River in the west (distant $19.50 \mathrm{~km}$ approximately) and the Piranhas-Assú River in the east (distant $25.00 \mathrm{~km}$ approximately), with a prevailing westbound current. This region is characterized by a semiarid and hot climate, with two distinct seasons: a dry (June to January) and a rainy season (February to May) with mean annual precipitation lower than 750 millimeters (Idema, 2008). The tides are semidiurnal; average sea level is 133.1 centimeters, the amplitude of the neap tide is $127.79 \mathrm{~cm}$ and the spring tide amplitude is $284.55 \mathrm{~cm}$ (Idema, 2003).

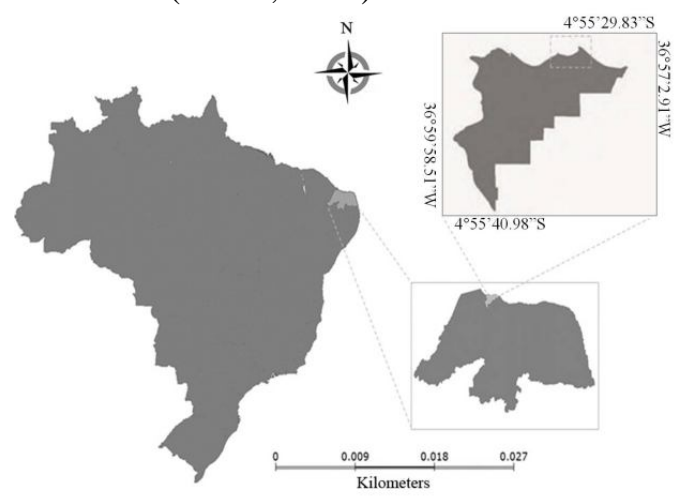

Figure 1 - Study area location map, São Cristóvão beach, Areia Branca municipality, Rio Grande do Norte, Brazil.

Samples were carried out in April, May, July, September and November 2011, always in high tide during spring tide period. A $15 \mathrm{~m}$ long and 8.6 $\mathrm{m}$ wide otter trawl net ( $4 \mathrm{~cm}$ mesh) was pulled by a shrimp boat with a $46 \mathrm{Hp}$, six-cylinder motor, at a speed of 2.5 knots. Two otter trawl samples were collected on the same day, one during the day and one at night. This otter trawl is the same fishing gear used in the region for shrimp fishery. Each haul lasted 15 minutes, which were conducted 
Diel fish assemblage variation in a sandy beach.

parallel to the coastal line, at a depth of 6 meters in the direction of the current. The fish captured were stored in a Styrofoambox, identified, measured (total length) and photographed at the Marine Fish Biology and Population Dynamics Laboratory. The samples were stored at this laboratory under the numbers 1-50.

The assemblage structure was evaluated regarding species abundance and frequency of occurrence for each period (diurnal and nocturnal). The methodology used for this classification was based on Garcia \& Vieira (2001). Species were considered abundant when the capture percentage $(\mathrm{CP} \%)$ was higher than $100 / \mathrm{S}$, where $\mathrm{S}$ is the number of species. Species with frequency of occurrence (FO) higher than $50 \%$ were considered frequent. After this analysis, species were classified according to their CP\% and FO\% (Table 1).

Table 1- Classification of fish species captured at São Cristóvão Beach (Rio Grande do Norte, Brazil) according to abundance and frequency of occurrence, based on the criteria proposed by Garcia \& Vieira (2001)

\begin{tabular}{ll}
\hline NA-I & CP $\%<100 / \mathrm{S}$ e FO $\% \leq 50 \%$ \\
NA-F & CP $\%<100 / \mathrm{S}$ e FO $\%>50 \%$ \\
A-I & CP $\%>100 / \mathrm{S}$ e FO $\% \leq 50 \%$ \\
A-F & CP $\%>100 / \mathrm{S}$ e FO $\%>50 \%$ \\
\hline
\end{tabular}

Legend: NA: not abundant, A: abundant, I: infrequent, F: frequent, CP: capture percentage, S: number of species, FO: frequency of occurrence.

Species were classified according to the trophic levels determined by Bouchon-Navaro et al. (1992), which place fish into the following categories: planktivores $(\mathrm{P})$ - food is composed mainly of plankton; omnivores $(\mathrm{O})$ - species that feed on invertebrates and at least $10 \%$ of algae; herbivores $(\mathrm{H})$ - from algae to seagrass; first order carnivores (IC) - small benthic invertebrates; second order carnivores (IIC) - invertebrates and fish; third order carnivores (IIIC) - fish makes up $80 \%$ of the food ingested. The species that were not evaluated by Bouchon-Navaro et al. (1992) and Paiva et al. (2009) were classified based on their food items, as available in the following website: www. fishbase.org. (Froese \& Pauly, 2014).

To characterize the fish assemblage, the Shannon's diversity index $\left(\mathrm{H}^{\prime}\right)$ was used and it is expressed in the equation $\mathrm{H}^{\prime}=-\Sigma$ (pi) $\left(\log _{2} \mathrm{pi}\right)$, where: "pi" is the quotient of the number of individuals of species "i" divided by the total number of individuals (Magurran, 1988); Primer 6.0 software was used (Primer-E 2009) for this analysis.

The density was calculated for each species in both periods (day and night), being density (d) expressed as the number of individuals for a given specie in relation to the sampled area. The values were standardized for an area of 100 square meters. The data were not normally distributed (Liliefors test), while variances were homoscedastic (Bartlett test). For this reason, the nonparametric Mann-Whitney test was used to compare variations in density, diversity index, trophic categories and total length of species between day and night periods. For this purpose, the software BioEstat 5.0 was used (Ayres et al., 2007).

A Bray-Curtis dissimilarity matrix was built based on square-root transformed data on fish density. From this matrix, samples were graphically represented by a non-metric multidimensional scaling (nMDS) ordination (Clarke, 1993). A permutational multivariate analysis of variance (PERMANOVA) (Anderson, 2001) was used to test the null hypothesis of no difference in fish community and trophic structures between diurnal and nocturnal periods, with the presence and absence of shoaling species which are likely to be present during the sampling. Statistical significance of PERMANOVA was tested with 4999 residuals permutations under an unrestricted permutation method and type III (partial) sums of squares. The similarity percentage analysis (SIMPER) (Clarke, 1993) was used to ascertain which species contributed the most with the dissimilarity between periods. All multivariate analyses were performed in Primer V6 \& PERMANOVA+ (Anderson \& Gorley, 2007).

\section{RESULTS}

Assessing the assemblage structure, 36 species belonging to 17 families were recorded. Of these, 33 occurred during the day and 23 at night, totaling 2189 and 1752 sampled individuals, respectively. Sciaenidae was the most representative family concerning the number of species and individuals in both periods (Table 2). 
Table 2 - Recorded species, in accordance with evolutionary order (Nelson 2006), at São Cristóvão beach, with respective families, trophic categories (TROPH. CAT.), capture percentage $(\mathrm{CP} \%)$, frequency of occurrence (FO\%), classification concerning percentage capture and frequency of occurrence (CPF) and density (DENS). Data sampled in April, May, July, September and November of 2011.

\begin{tabular}{|c|c|c|c|c|c|c|c|c|c|c|}
\hline FAMILY & SPECIES & $\begin{array}{l}\text { TROPH. } \\
\text { CAT. }\end{array}$ & $\begin{array}{l}\text { PC\% } \\
\text { DAY }\end{array}$ & $\begin{array}{c}\text { PC\% } \\
\text { NIGHT }\end{array}$ & $\begin{array}{l}\text { FO\% } \\
\text { DAY }\end{array}$ & $\begin{array}{c}\text { FO\% } \\
\text { NIGHT }\end{array}$ & $\begin{array}{l}\text { CPF } \\
\text { DAY }\end{array}$ & $\begin{array}{c}\text { CPF } \\
\text { NIGHT }\end{array}$ & $\begin{array}{l}\text { DENS } \\
\text { DAY }\end{array}$ & $\begin{array}{c}\text { DENS } \\
\text { NIGHT }\end{array}$ \\
\hline Ophichthidae & Ophichthus gomesi (Castelnau, 1855) & II Carnivore & 0.04 & - & 20 & - & NA-I & - & 0.002 & - \\
\hline Pristigasteridae & Chirocentrodon bleekerianus (Poey, 1867) & III Carnivore & 70.81 & 1.48 & 100 & 80 & $\mathrm{~A}-\mathrm{F}$ & NA-F & 3.11 & 0.05 \\
\hline Pristigasteridae & Pellona harroweri (Fowler, 1917) & I Carnivore & 7.44 & 1.94 & 100 & 100 & $\mathrm{~A}-\mathrm{F}$ & NA-F & 0.33 & 0.07 \\
\hline Engraulidae & Anchoa januaria (Steindachner, 1879) & Omnivore & 0.04 & - & 20 & - & NA-I & - & 0.002 & - \\
\hline Engraulidae & Anchoa spinifer (Valenciennes, 1848) & II Carnivore & 0.36 & 0.06 & 80 & 20 & NA-F & NA-I & 0.02 & 0.002 \\
\hline Engraulidae & Anchoa tricolor (Agassiz, 1829) & I Carnivore & 0.04 & 0.06 & 20 & 20 & NA-I & NA-I & 0.002 & 0.002 \\
\hline Clupeidae & Opisthonema oglinum (Lesueur, 1818) & II Carnivore & - & 0.44 & - & 20 & - & NA-I & - & 0.01 \\
\hline Ariidae & Bagre bagre (Linnaeus, 1766) & II Carnivore & 0.23 & - & 40 & - & NA-I & - & 0.01 & - \\
\hline Ariidae & Bagre Marinus (Mitchill, 1815) & II Carnivore & 0.32 & 1.83 & 20 & 40 & NA-I & NA-I & 0.01 & 0.06 \\
\hline Ariidae & Cathorops spixii (Agassiz, 1829) & II Carnivore & 1.28 & 13.70 & 80 & 100 & NA-F & $\mathrm{A}-\mathrm{F}$ & 0.06 & 0.48 \\
\hline Carangidae & Chloroscombrus chrysurus (Linnaeus, 1766) & Omnivore & 0.09 & - & 40 & - & NA-I & - & 0.004 & - \\
\hline Carangidae & Selene setapinnis (Mitchill, 1815) & II Carnivore & 0.59 & 0.11 & 60 & 20 & NA-F & NA-I & 0.03 & 0.004 \\
\hline Carangidae & Selene vomer (Linnaeus, 1758) & II Carnivore & 0.27 & 0.17 & 40 & 20 & NA-I & NA-I & 0.01 & 0.01 \\
\hline Lutjanidae & Lutjanus synagris (Linnaeus, 1758) & II Carnivore & 0.14 & 0.11 & 60 & 40 & NA-F & NA-I & 0.01 & 0.004 \\
\hline Haemulidae & Conodon nobilis (Linnaeus, 1758) & II Carnivore & 0.46 & 0.51 & 80 & 20 & NA-F & NA-I & 0.02 & 0.02 \\
\hline Haemulidae & Genyatremus luteus (Bloch, 1790) & I Carnivore & 0.09 & - & 40 & - & NA-I & - & 0.004 & - \\
\hline Haemulidae & Pomadasys corvinaeformis (Steindachner, 1868) & II Carnivore & 0.68 & 1.03 & 40 & 80 & NA-I & NA-F & 0.03 & 0.04 \\
\hline Sparidae & Archosargus probatocephalus (Walbaum, 1792) & I Carnivore & 0.04 & - & 20 & - & NA-I & - & 0.002 & - \\
\hline Polynemidae & Polydactylus virginicus (Linnaeus, 1758) & Omnivore & 0.18 & 0.80 & 40 & 80 & NA-I & NA-F & 0.01 & 0.03 \\
\hline Sciaenidae & Bairdiella ronchus (Cuvier, 1830) & II Carnivore & 0.46 & - & 20 & - & NA-I & - & 0.02 & - \\
\hline Sciaenidae & Cynoscion microlepidotus (Cuvier, 1830) & II Carnivore & 0.04 & - & 20 & - & NA-I & - & 0.002 & - \\
\hline Sciaenidae & Isopisthus parvipinnis (Cuvier, 1830) & I Carnivore & 1.14 & 3.54 & 60 & 80 & NA-F & NA-F & 0.05 & 0.12 \\
\hline Sciaenidae & Larimus breviceps Cuvier, 1830 & I Carnivore & 7.54 & 35.85 & 100 & 100 & $\mathrm{~A}-\mathrm{F}$ & $\mathrm{A}-\mathrm{F}$ & 0.33 & 1.26 \\
\hline Sciaenidae & Menticirrhus americanus (Linnaeus, 1758) & I Carnivore & 1.37 & 1.59 & 80 & 80 & NA-F & NA-F & 0.06 & 0.06 \\
\hline
\end{tabular}

Braz. Arch. Biol. Technol. v.59: e16160076, Jan/Dec 2016 
Diel fish assemblage variation in a sandy beach.

\begin{tabular}{|c|c|c|c|c|c|c|c|c|c|c|}
\hline FAMILY & SPECIES & $\begin{array}{c}\text { TROPH. } \\
\text { CAT. }\end{array}$ & $\begin{array}{l}\text { PC\% } \\
\text { DAY }\end{array}$ & $\begin{array}{c}\text { PC\% } \\
\text { NIGHT } \\
\end{array}$ & $\begin{array}{l}\text { FO } \% \\
\text { DAY }\end{array}$ & $\begin{array}{c}\text { FO\% } \\
\text { NIGHT }\end{array}$ & $\begin{array}{l}\text { CPF } \\
\text { DAY }\end{array}$ & $\begin{array}{c}\mathrm{CPF} \\
\text { NIGHT }\end{array}$ & $\begin{array}{l}\text { DENS } \\
\text { DAY }\end{array}$ & $\begin{array}{c}\text { DENS } \\
\text { NIGHT }\end{array}$ \\
\hline Sciaenidae & Stellifer rastrifer (Jordan, 1889) & I Carnivore & 3.11 & 22.94 & 80 & 100 & A-F & A-F & 0.14 & 0.81 \\
\hline Sciaenidae & Stellifer stellifer (Jordan; Snyder, 1902) & I Carnivore & 0.55 & 6.39 & 40 & 80 & NA-I & A-F & 0.02 & 0.22 \\
\hline Trichiuridae & Trichiurus lepturus Linnaeus, 1758 & II Carnivore & 0.09 & - & 20 & - & NA-I & - & 0.004 & - \\
\hline Paralichthydae & Citharichthys spilopterus Günther, 1862 & I Carnivore & 0.04 & - & 20 & - & NA-I & - & 0.03 & 0.03 \\
\hline Paralichthydae & Citharichthys macrops Dresel, 1889 & I Carnivore & 0.64 & 0.80 & 40 & 60 & NA-I & NA-F & 0.002 & - \\
\hline Achiridae & Trinectes paulistanus (Miranda Ribeiro, 1915) & I Carnivore & 0.55 & 2.74 & 80 & 80 & NA-F & NA-F & 0.02 & 0.1 \\
\hline Cynoglossidae & Symphurus plagusia (Bloch; Schneider, 1801) & I Carnivore & - & 0.91 & - & 80 & - & NA-F & - & 0.03 \\
\hline Cynoglossidae & Symphurus tesselatus (Linnaeus, 1766) & I Carnivore & 0.04 & - & 20 & - & NA-I & - & 0.002 & - \\
\hline Tetraodontidae & Sphoeroides greeleyi Gilbert, 1900 & I Carnivore & 0.14 & - & 60 & - & NA-F & - & 0.01 & - \\
\hline Diodontidae & Chilomycterus spinosus spinosus (Linnaeus, 1758) & I Carnivore & 0.09 & - & 20 & - & NA-I & - & 0.004 & - \\
\hline
\end{tabular}


The species Micropogonias furnieri (Desmarest, 1823), Opisthonema oglinum (Lesueur, 1818) and Symphurus plagusia (Bloch; Schneider, 1801) were caught only at night.

During daytime, four species (Chirocentrodon bleekerianus (Poey, 1867), Larimus breviceps Cuvier, 1830, Pellona harroweri (Fowler, 1917) and Stellifer rastrifer (Jordan, 1889) were considered abundant and frequent (A-F). At night, four species Cathorops spixii (Agassiz, 1829), $L$. breviceps Cuvier, 1830, S. rastrifer (Jordan, 1889) and Stellifer stellifer (Jordan; Snyder, 1902) were also recorded as abundant and frequent (A-F) (Table2, Figure 2).

The non-metric multidimensional scaling ordination showed the formation of two different groups, suggesting segregation in the fish assemblage between diurnal and nocturnal periods (Figure 3). This segregation was confirmed by PERMANOVA results (Table 3). The PERMANOVA analysis was also redone after the removal of the shoaling species $C$. bleekerianus and $P$. harroweri from the data to confirm this result. The analysis confirmed that, even in the absence of shoals, there are differences between the densities at day and night periods (Table 4).

The SIMPER analysis demonstrated that six species contributed together with over $85 \%$ of the dissimilarity between diurnal and nocturnal periods. Species with higher percentage contributions were $C$. bleekerianus and $L$. breviceps (Table 5).
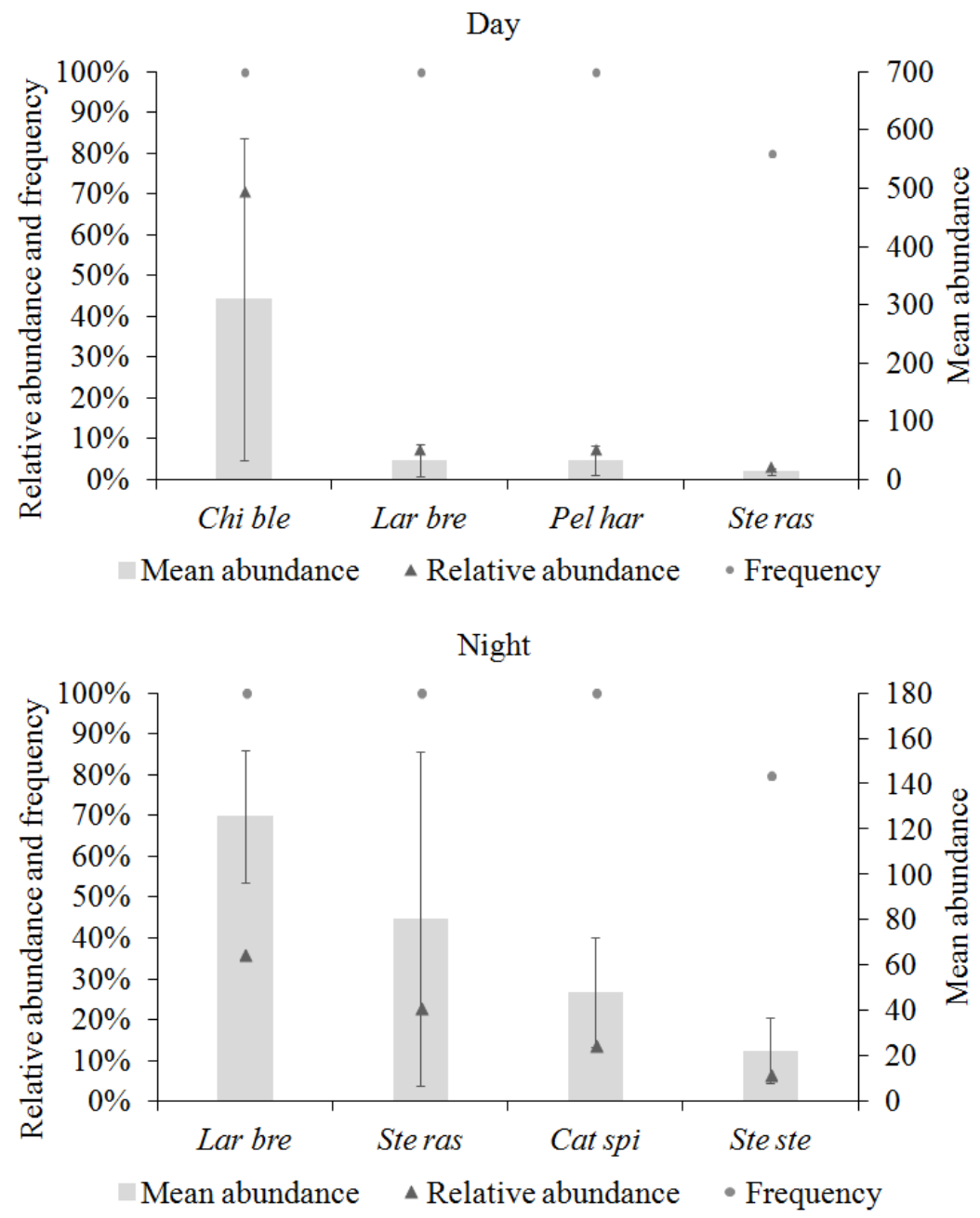

Figure 2 - Relative abundance, mean abundance with standard deviation and frequency of occurrence of abundant and frequent fish species caught at São Cristóvão beach, Brazil, for day and night periods. Data sampled in April, May, July, September and November of 2011. Legend: Chi ble: Chirocentrodon bleekerianus; Lar bre: Larimus breviceps; Pel har: Pellona harroweri; Ste ras: Stellifer rastrifer; Cat spi: Cathorops spixii; Ste ste: Stellifer stellifer 
Diel fish assemblage variation in a sandy beach.

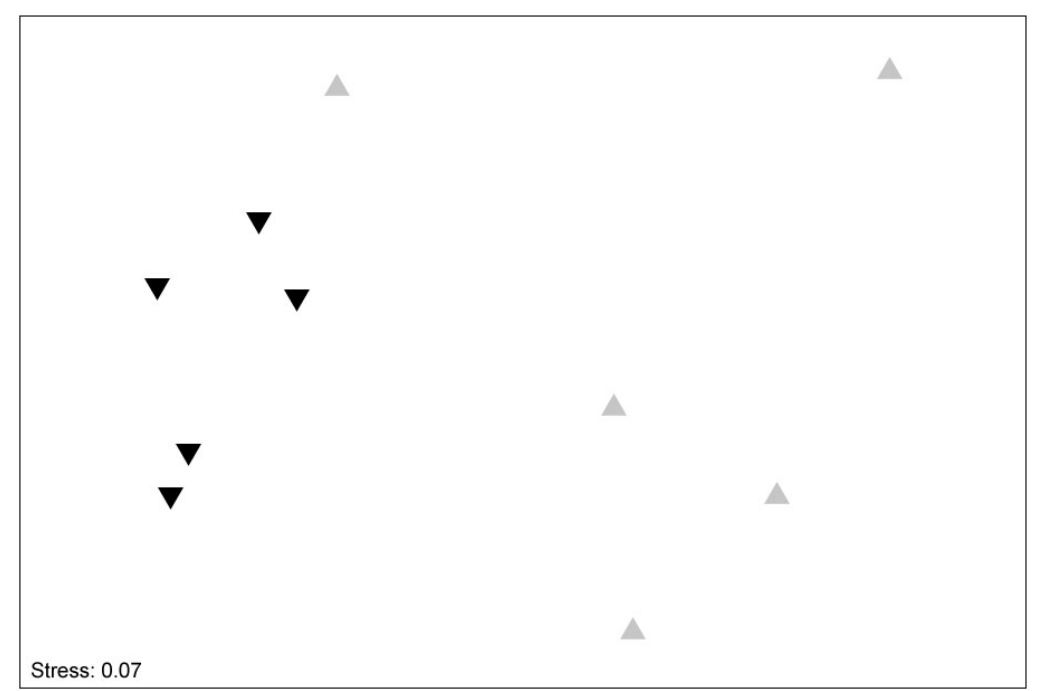

Figure 3 - The non-metric multidimensional scaling ordination (nMDS) of samples performed at diurnal (light triangles) and nocturnal (dark triangles) periods at São Cristóvão beach, Brazil. Data sampled in April, May, July, September and November of 2011.

Table 3- PERMANOVA results based on density values (individuals. $100 \mathrm{~m}^{-2}$ ) of sampled species at São Cristóvão beach, Brazil. Data sampled in April, May, July, September and November of 2011.

\begin{tabular}{cccccccc}
\hline Source & df & SS & MS & Pseudo-F & P(perm) & P (Monte Carlo) & Unique perms \\
\hline Periods & 1 & 4683 & 4683 & 4.33 & 0.007 & 0.012 & 126 \\
Residuals & 8 & 8647.4 & 1080.9 & & & & \\
Total & 9 & 13330 & & & & & \\
\hline
\end{tabular}

Table 4 - PERMANOVA results based on density values (indiv. $100 \mathrm{~m}^{-2}$ ) of sampled species without shoaling ones at São Cristóvão beach, Brazil. Data sampled in April, May, July, September and November of 2011.

\begin{tabular}{cccccccc}
\hline Source & df & SS & MS & Pseudo-F & P(perm) & P (Monte Carlo) & Unique perms \\
\hline Periods & 1 & 3791.1 & 3791.1 & 3.21 & 0.009 & 0.022 & 126 \\
Residuals & 8 & 9432.7 & 1179.1 & & & & \\
Total & 9 & 13224 & & & & & \\
\hline
\end{tabular}

Table 5 - SIMPER results based on density values (indiv. $100 \mathrm{~m}^{-2}$ ) of species that contributed most for the dissimilarity between day and night periods. The values are presented in descending order of percentage contribution. Data sampled in April, May, July, September and November of 2011.

\begin{tabular}{ccccc}
\hline Species & \multicolumn{2}{c}{ Mean density } & Contribution & Cumulative cont. \\
\cline { 2 - 3 } C. bleekerianus & Day & Night & $(\%)$ & $(\%)$ \\
L. breviceps & 3.11 & 0.05 & 39.62 & 39.62 \\
S. rastrifer & 0.33 & 1.26 & 17.25 & 56.87 \\
C. spixii & 0.14 & 0.81 & 10.87 & 67.74 \\
P. harroweri & 0.06 & 0.48 & 8.11 & 75.85 \\
S. stellifer & 0.33 & 0.07 & 5.89 & 81.74 \\
Mean dissimilarity $=77.09$ & 0.02 & 0.23 & 4.07 & 85.81 \\
\hline
\end{tabular}

Comparing species densities between periods, it was verified that only $L$. breviceps and $C$. spixii were significantly more numerous at night (both with $\mathrm{p}$ values $=0.02 ; \mathrm{Z}(\mathrm{U})=1.0)$ and $C$. bleekerianus during the day $(\mathrm{p}=0.04$ and $\mathrm{Z}(\mathrm{U})=$ 2.5).
No statistical difference was observed for diversity $($ day $=1.26 \pm 0.46$; night $=1.74 \pm 0.16)$ of fish assemblage between diurnal and nocturnal periods (diversity $-\mathrm{Z}(\mathrm{U})=1.2534$ and $\mathrm{p}=0.1050)$.

Amongst trophic categories, first order carnivores $(\mathrm{IC}=1.921$ individuals $)(\mathrm{p}=0.02 ; \mathrm{Z}(\mathrm{U})=1.0)$ and third order carnivores (IIIC $=1.550$ 
individuals $)(\mathrm{p}=0.046 ; \mathrm{Z}(\mathrm{U})=2.5)$ were significantly more representative during the night and the day, respectively (Figure 4). The category of third order carnivores was represented exclusively by $C$. bleekerianus, which was statistically more abundant during daytime.

Regarding the total length of fish, only four species presented significant differences between periods. Isopisthus parvipinnis (Cuvier, 1830) and Conodon nobilis (Linnaeus, 1758) presented individuals of greater length during the day, while individuals of Pomadasys corvinaeformis (Steindachner, 1868) and Bagre marinus (Mitchill, 1815) were bigger at night. (Figure 5).

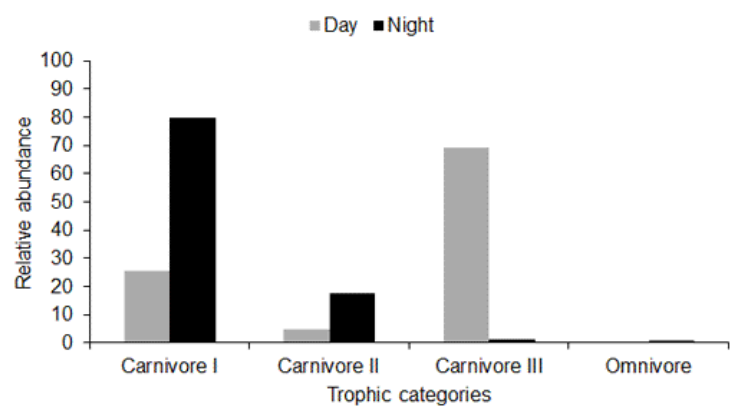

Figure 4 - Relative abundance of trophic categories at diurnal and nocturnal periods at São Cristóvão beach, Brazil.
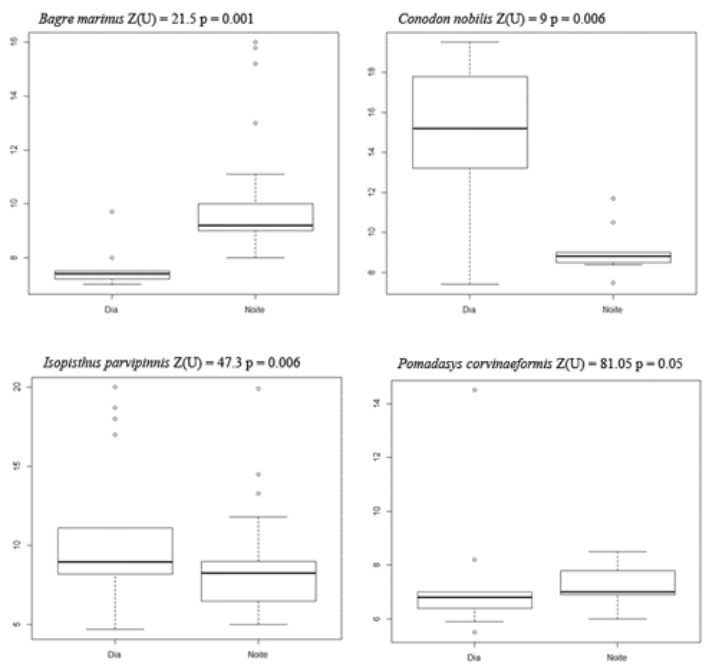

Figure 5 - Species that showed significant differences for total lengths between diurnal and nocturnal periods. Box plots show the interquartile range, with whiskers indicating confidence intervals. The horizontal lines indicate median values and circles represent the outliers of the total length that presented greater variability.

\section{DISCUSSION}

The São Cristóvão sandy beach is composed by a diverse fish assemblage and some species are abundant and common in day and night periods. In Brazil, it is noticeable that Sciaenidae contributes with the largest number of species (LoweMcConnell, 1999) and it is mentioned as the richest and most abundant family in several Brazilian studies concerning sandy beach ecosystems (Godefroid et al., 2004; Freitas et al., 2011; Dantas et al., 2012).

The occurrence of few dominant species, either in number or in biomass, and the presence of many occasional and sporadic species is a commonly observed pattern in sandy beaches (Godefroid et al., 2003; Felix et al., 2007, Dantas et al., 2012). This pattern was observed in this study due to the considerable number of species classified as not abundant and infrequent and as not abundant and frequent.

Only Micropogonias furnieri, Opisthonema oglinum and Symphurus plagusia occurred exclusively at nocturnal periods. However, due to the low abundance and frequency of occurrence in the samples, it is not possible to state that these species occur mainly in the night period.

The most numerous species during the day (Chirocentrodon bleekerianus and Pellona harroweri) usually form shoals, which are generally larger and more common during the day (Helfman, 1993; Oliveira-Neto et al., 2008). In shoals, these species are more protected from visual predators such as fish and seabirds (FélixHackradt et al., 2010). However, the observed variations in densities between periods did not occur only by the presence of shoals (PERMANOVA analysis without shoaling species), but also because of the representativeness of species that were sampled more at night (Larimus breviceps, Stellifer rastrifer, Cathorops spixii and Stellifer stellifer). This result substantiates that the dissimilarity occurred mainly due to the influence of these six species densities. Besides, diel activities of fish species, especially juveniles, may differ from one area to another, even for a given species (Vasconcellos et al., 2010). Thus, the possible causes of such changes require further investigation.

Biological interactions can influence the diel differences in abundance, richness and diversity of fish assemblages in sandy beaches. Some of these 
Diel fish assemblage variation in a sandy beach.

interactions are predation (many species remain sheltered during the day and are active at night to avoid visually orientated predators), behavioral aspects (larger individuals with a higher swimming capability can avoid fishing nets during periods of light) and local features (presence of macroalgae beds can provide shelter and food) (Galzer \& Zalmon, 2008). In this study, the diversity index did not present differences between periods. Another studies also related no correlation among ecological indexes and diel variations observed in the assemblage (Pessanha \& Araújo, 2003; Félix-Hackradt 2010). It is important to mention that this region is poorly studied and it is not known if there are seagrass and macroalgae beds in the vicinity of the sampled area, for example. The presence of seagrass beds is cited in some researches as being one of the main reasons for differences and variations recorded in fish assemblage between day and night periods, e.g. Galzer \& Zalmon, (2008) and Jarrin \& Shanks (2011).

Fishes that feed on mobile invertebrates are expected to be abundant on soft bottoms, since crustaceans, molluscs and polychaetes are food resources that can achieve high abundance and biomass within sandy beach ecosystems (Schlacher et al., 2008). It is suggested that, at night, the behavior of endobenthic species, mostly composed by crustacean decapods, is influenced by light (Aguzzi et al., 2015). These species emerge from the sediment at night and return to their diurnal shelters at daytime. This behavior can be considered as a trade-off between natural mortality due to predation and energy gains (Aguzzi et al., 2015). Thus, the most primitive fish species, with more generalist oral apparatus, such as catfish, grunts and drums, would benefit from those more vulnerable preys at night (Hobson, 1976). Besides, demersal species use to move more actively during the night in search for small crustaceans, which are their main food items (Maes et al., 1999; Pesanha et al 2003b). The fact that first order carnivores had shown high density at night is mainly associated with $L$. breviceps and C. spixii, which were the most abundant species during this period.

C. bleekerianus is a piscivore or third order carnivore as adult, feeding mainly on small fish (Sazima et al., 2004; Corrêa et al., 2005). Based on the length of first sexual maturity $(76 \mathrm{~mm}$ ) (Corrêa et al., 2005), $90 \%$ of C. bleekerianus sampled was composed of adults. This fact demonstrates the availability of small fish in the sampling area. Besides this, it is possible that herrings rely mainly on vision to capture their prey. Thus, its high density during the day may have been favored by the presence of light, as observed in Trachinotus carolinus (Linnaeus, 1766) in Guanabara Bay (Rio de Janeiro, Brazil) during the day (Vasconcelos et al., 2010).

Length differences among sampled individuals during the day and at night can be attributed to the nocturnal habits of adult fish, which are less numerous and sociable, but are greater in size and biomass (Vasconcellos et al., 2010). However, only Pomadasys corvinaeformis and Bagre marinus presented statistically higher lengths at night compared to the diurnal period. In a study performed at Pontal do Sul beach, Paraná, it was verified that the capture of individuals of $P$. corvinaeformis with greater weights was more expressive at night than during the day (Godefroid et al., 1998). This may be attributed to their closeness to the shallow coastal zone to avoid predators that rely mainly on vision to search for preys (Abou-Seedo et al., 1990; Félix-Hackradt 2010). There are many reasons for juvenile and small-sized fishes to approach shallow and coastal areas. One of these reasons is the search for shelter and refuge from predators in subtidal zones (Wright, 1989; Gibson et al. 1996; Pesanha et al. 2003b; Dulcic et al. 2004). Also, it is believed that the lack of larger fish at night is related to the low depth of the beach, which is naturally shallow. Thus, this low depth does not allow the establishment of adult larger fish, providing a safe environment for juveniles and small species at any time of the day. This statement is reinforced by the fact that the only species that feed on fish is the small clupeiform C. bleekerianus, considered as top predator in this research.

In accordance with the obtained results, it can be suggested that the demersal fish assemblage of São Cristóvão beach presented variations regarding the density of individuals between diurnal and nocturnal periods, but such variations were not observed for diversity and richness indexes. Dissimilarities were also recorded in trophic categories and in total lengths of individuals; however this occurred due to the high density of some species. Moreover, the low depth of the beach may prevent the establishment of adult fish larger size, thus becoming a favorable environment for juveniles and small-sized species. These results reinforce the need for more specific 
researches to achieve a better understanding of the dynamics of fish assemblage in sandy beaches.

\section{REFERENCES}

Abou-Seedo, F., Clayton, D. A. \& Wright, J.M., 1990. Tidal and turbidity effects in the shallowwater fish assemblage of Kwait Bay. Marine Ecology Progress Series 65:213-233.

Aguzzi, J., Sbragaglia, V., Tecchio, S., Navarro, J., Company, J. B., 2015. Rhythmic behaviour of marine benthopelagic species and the synchronous dynamics of benthic communities. Deep-Sea Research I 95: 1-11.

Anderson, M. J, 2001. A new method for nonparametric multivariate analysis of variance. Australian Ecology 26: 32-46.

Anderson, M. J. \& Gorley, R. N, 2007. PERMANOVA+ for PRIMER: Guide to software and statistical methods. Plymouth: PRIMER-E.

Ayres, M., Ayres Júnior, M. \& Santos, A.A.S, 2007.BioEstat - Aplicações estatísticas nas áreas das ciências biomédicas.

Beyst B., Buysse D., Dewicke A., Mees J., 2001. Surf zone hyperbenthos of Belgian sandy beaches: seasonal patterns. Estuarine, Coastal and Shelf Science 53: 877-895.

Bouchon-Navarro, Y., Bouchon, C. \& Louis, M, 1992.L'ichtyofaunedesherbiers de phanérogames marines de labaie de Fort-de-France (Martinique, AntillesFrançcaises). Cybium 16: 307 - 330.

Clark, B. M., Bennett, B. A. \&Lamberth, S. J, 1996.Factors affecting spatial variability in seine net catches of fish in the surf zone of False Bay, South Africa. Marine ecology progress series 31: 17 - 34 . Clarke, K.R, 1993. Non-parametric multivariate analyses of changes in community structure. Australian Journal of Ecology 18: 117-143. Corrêa, C.E., Chaves, P.T. \& Guimarães, P.R, 2005. Biology of Chirocentrodonbleekerianus(Poey, 1867) (Clupeiformes: Pristigasteridae) in a Continental Shelf Region of Southern Brazil. Brazilian Archives of Biology and Technology 48: 419 - 427.

Dantas, N.C.F.M., Araújo, M.E. \& Feitosa, C.V, 2012. Composition and assemblage structure of demersal fish from São Cristóvão beach, Areia Branca, RN. Biota Neotropica12: $1-10$.

Félix, F.C., Spach, H.L., Moro, P.S., Schwarz-Jr, R., Santos, C., Hackradt, C.W. \& Hostim-Silva, M, 2007. Utilization patterns of surf zone inhabiting fish from beaches in Southern Brazil. Pan-American Journal of Aquatic Science2: 27 - 39.

Félix-Hackradt, F.C., Spach, H.L., Moro, P. S., Pichler, H. A., Maggi, A. S., Hostim-Silva, M. \& Hackradt, C.W., 2010. Diel and tidal variation in surf zone fish assemblages of a sheltered beach in southern Brazil. Lat. American Journal of Aquatic Research 38: 447-460.
Freitas, M.O., Spach, H.L. \& Hostim-Silva. M., 2011. Variação espaço-temporal da assembleia de peixes demersais em uma área de pesca do camarão sete-barbas no sul do Brasil. Neotropical Biology and Conservation 6: $44-54$.

Froese, R. \& Pauly, D, 2014. FishBase. World Wide Web electronic publication. www.fishbase.org, version (08/2014).

Gaelzer, L.R. \&Zalmon, I.R, 2008. Diel variation of fish community in sandy beaches of Southeastern Brazil. Brazilian Journal of Oceanography 56: 23 39.

Garcia, M.A. \& Vieira, J.P, 2001.0 aumento da diversidade de peixes no estuário da lagoa dos Patos durante o episódio El niño. Atlântica 23: 85 - 96.

Gibson, R.N., Robb, L., Burrows, M.T. \& Ansell, A.D., 1996. Tidal, diel and longer term changes in the distribution of fishes on a Scottish sandy beach. Marine Ecology Progress Series 130:1-17.

Godefroid, R.S., Hofstaetter, M., \& Spach, H. L., 1998. Moon, tidal and diel influences on catch composition of fishes in the surf zone of Pontal do Sul beach, Paraná. Brazilian Journal of Biology 15: 697-701.

Godefroid, R.S., Spach, H.L., Santos, C., Macnaren, G. \& Schwarz Jr, R, 2004. Mudanças temporais na abundância e diversidade da fauna de peixes do infralitoral raso de uma praia, sul do Brasil. Iheringia, Série Zoologia, 94: 95 - 104.

Godefroid, R.S., Spach, H.L., Schwarz Junior, R. \&Queiroz, G.M, 2003. A fauna de peixes da praia do balneário Atami, Paraná, Brasil. Atlântica, 25: $147-161$.

Griffiths, S.P, 2001. Diel variation in the seagrass ichthyofaunas of three intermittently open estuaries in south-eastern Australia: implications for improving fish diversity assessments. Fisheries Management and Ecology 8: 123-140.

Hagan, S.M. \& Able, K.W, 2008.Diel variation in the pelagic fish assemblage in a temperate estuary. Estuaries and Coasts: J CERF 31: 33-42.

Helfman G.S, 1993. Fish behaviour by day, night and twilight. In Tony J.P (ed) Pitcher Behaviour of teleost fishes.Londres: $479-512$.

Hobson E. S, 1965. Diurnal-nocturnal activity of some inshore fishes in the Gulf of California. Copeia: $291-302$.

IDEMA, 2003. Relatório final dos estudos para implementação do ZEE dos estuários do Rio Grande do Norte e seus entornos. Instituto de Desenvolvimento econômico e Meio Ambiente do Rio Grande do Norte. Natal: Subcoordenadora de Gerenciamento Costeiro.

IDEMA, 2008. Perfil do Estado do Rio Grande do Norte. Instituto de Desenvolvimento Econômico e Meio Ambiente do Rio Grande do Norte. Natal: Secretaria de Estado do Planejamento e das Finanças do Rio Grande do Norte. 
Diel fish assemblage variation in a sandy beach.

INSTITUTO BRASILEIRO DO MEIO AMBIENTE E DOS RECURSOS NATURAIS RENOVÁVEIS - IBAMA, 2007.Estatística da pesca 2005 - Brasil, grandes regiões e unidades da federação. Brasília: Diretoria da Fauna e Recursos Pesqueiros.

Dulcic, J., Fencilo, M., Matic.-Skoko, S., Kraljevic, M \& Glamuzina, B., 2004. Diel catch variations in a shallow-water fish assemblage at Duce Glava, eastern Adriatic (Croatian coast). Journal of Marine Biological Association of United Kingdom 84: 659 - 664.

Jarrin, J.R.M \& Shanks, A.L., 2011. Spatiotemporal dynamics of the surf-zone faunal assemblages at a Southern Oregon sandy beach. Marine Ecology 32: 232-242.

Lowe-McConnel, R.H, 1999. Estudos Ecológicos de Comunidades de Peixes Tropicais. São Paulo (ed): EdUSP.

Maes J., Pas, J., Taillieu, A., Van Damme, P.A., Ollevier, F., 1999. Diel changes in the vertical distribution of juvenile fish in the Zeeschelde Estuary. Journal of Fish Biology 54:1329-1333.

Magurran, A.E, 1988. Ecological Diversity and Its Measurement(ed). New Jersey: Princeton University press.

Morrison, M.A., Francis, M.P., Hartill, B.W. \& Parkinson, D.M, 2002. Diurnal and tidal variation in the abundance of the fish fauna of a temperate tidal mudflat. Estuarine, Coastal and Shelf Science 54: 793-807.

Nagelkerken, I., Dorenbosch, M., Verberk, W.C.E.P. Cocheret de La Morinière, E. \& Van Der Velde, G, 2000. Day-night shifts of fishes between shallow-water biotopes of a Caribbean bay, with emphasis on the nocturnal feeding of Haemulidae and Lutjanidae. Marine Ecology Progress Series 194: 55-64.

Nash, R.D.M. \& Santos R.S, 1998.Seasonality in diel catch rate of small fishes in a shallow-water fish assemblage at Porto Pim Bay, Faial, Azores. Estuarine, Coastal and Shelf Science 47: 319-328.

Oliveira Neto, J.F., Spach, H.L., Schwarz Junior \&R., Pichler, H.A, 2008.Diel variation in fish assemblages in tidal creeks in southern Brazil. Brazilian Journal of Biology 68:37-43.

Paiva, A.C.G., Chaves, P.T.C. \&Araújo, M.E, 2009.Spatial distribution of the estuarine ichthyofauna of the Rio Formoso (Pernambuco, Brazil), with emphasis on reef fish. Zoologia 26: 266-278.

Parsley M.J., Palmer D.E. \& Burkhardt R.W, 1989. Variation in capture efficiency of a beach seine for small fishes. North American Journal of Fisheries Management 9: 239-244.

Pessanha, A.L.M. \& Araujo, F.G, 2003. Spatial, temporal and diel variations of fish assemblages at two sandy beaches in the Sepetiba Bay, Rio de
Janeiro, Brazil. Estuarine, Coastal and Shelf Science 57: 817-828.

Pessanha, A. L. M., Araújo, F. G., Azevedo, M. C. C., Gomes, I. D., 2003. Diel and seasonal changes in the distribution of fish on a southeast Brazil sandy beach. Marine Biology 143: 1047-1055.

Primer-E, 2009.Plymouth Routines In Multivariate Ecological Research. 1st edition. Plymouth: Plymouth Marine Laboratory.

Ribeiro, J., Bentes, L., Coelho, R., Gonçalves, J.M.S., Lino, P.G., Monteiro, P. \& Erzini, K, 2006. Seasonal, tidal and diurnal changes in fish assemblages in the Ria Formosa Lagoon (Portugal). Estuarine, Coastal and Shelf Science 67: 461-474.

Rountree, R.A. \& Able, K.W, 1993.Diel variation in decapoda crustacean and fish assemblages in New Jersey polyhaline marsh creeks.Estuarine, Coastal and Shelf Science 37: $181-201$.

Sazima, C., Moura, R. L. \& Sazima, I, 2004.Chirocentrodon bleekerianus (Teleostei: Clupeiformes: Pristigasteridae), a small predaceous herring with folded and distinctively oriented prey in stomach. Brazilian Journal of Biology 64: 165 168.

Schlacher, T.A., Schoeman, D.S, Dugan, J., Nastra, M., Jones, A., Scapini, F. \& McNachnan, A, 2008. Sandy beach ecosystems: key features, sampling issues, management challenges and climate change impacts. Marine Ecology 29: 70 - 90.

Vasconcellos, R.M., Araújo, F.G., Santos, J.S. and Silva, M.A, 2010. Diel seasonality in fish biodiversity in a sandy beach in south-eastern Brazil.Journal of the Marine Biological Association of the United Kingdom 91: $1337-1344$.

Wright, J.M., 1989. Diel variation and seasonal consistency in the fish assemblage of the nonestuarine Sulaibikhat Bay, Kuwait. Marine Biology 102: 135 - 142.

Received: January 15, 2016 Accepted: May11, 2016 